ISSN 1991- 8690

Website: http://jsci.utq.edu.iq

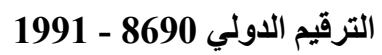

\title{
In vitro activity of Triazolo[1,5-a] pyrimidine carboxylic acid extracted from microalgae Hapalosiphon welweschii againstTrichomonas vaginalis
}

\author{
Amal KH. Khalaf \\ * Ahmed H. Mohammad \\ *Dept. Microbiology _ Coll. Medicine_Thi_qar University \\ **Dept Of Pharmacology _ Coll. Medicine _ Thi_Qar University \\ E-mail:dr.amalkhalaf@yahoo.com
}

Tel:07802521845

\begin{abstract}
:
The present study targets the protozoan parasite Trichomonas vaginalis that causes a healthy problems among women and rarely among men, by the application of natural product or secondary metabolites extracted from the microalgae Hapalosiphon welweschii for the first time in Iraq . methanol extract was explained high activity in three concentration recording $100 \%$ of parasite death at $200 \mu \mathrm{g} / \mathrm{ml}$ of methanol extract in about two days while 150 and $100 \mu \mathrm{g} \backslash \mathrm{ml}$ of extract reports activity against the parasite after three and four days post treatment respectively . GCMass spectrum of the methanol extract has explain presence of the compound Triazolo[1,5-a] pyrimidine carboxylic acid in about $13.28 \%$ from the total composition of methanol extract of microalgae $H$. welweschii .
\end{abstract}

Key words : STD, T. vaginalis, methanol extract .

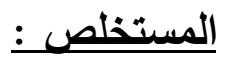

استهدفت الدراسة الحاليه طفيلي المشعره المهبليه الذي يسبب مشاكل صحيه للنساء ونادرا للرجال ، من خلال استعمال المركبات الطبيعية او مركبات

الايض الثانوي المعزوله من من الطحلب الاخضر المزرق الاقيق Helweschii ولاول مره في العراق ـ فقد لوحظ هناك فعاليه عاليه للمستخلص

المثانولي وبثلاث تراكيز مسجلة 100\% نسبة فعاليه للتركيز 200 مايكروغرام ا مللتر لهذا المستخلص وخلال يومين فقط في حين بين كل من التركيزين

150 و 100 مايكروامللتز الفعاليه نفسها ولكن بعد مرور ثناث واربعة ايام على التوالي • وبين التحليل الكيميائي لمستخلص الميثانول لهذا الطحلب

باستعمال تقنية كروموتوكرافيا الغاز طيف الكتله احتواءه على نسبه عاليه من المركب Triazolo[1,5-a] pyrimidine carboxylic acid حوالي

• 13.28 \% من المستخلص

الكلمات المفتاحية : الامراض المنتقله جنسياً ، طفيلي المشعرة المهبليه ، المستخلص الميثانولي

\section{Introduction :}

Trichomoniasis is a sexually transmitted disease (STD) with important health ramification ; it has been associated with vaginatis, Urethritis, and pelvic inflammatory disease (PID). Trichomoniasis also impacts upon birth outcomes and is co - factor in human immunodeficiency virus (HIV) transmission and acquisition (Swygard etal., 2004) . Symptoms in women with Trichomoniasis include vaginal discharge, dysuria , and pruritus . in men symptoms include the urethral discharge, urethral pruritus, and dysuria (Schwebke and Burgess 2004). Approximately 180 million women worldwide may be infected with $T$. vaginalis . Prevalence estimates vary between population studies, but ranging from 5-74 \% in women and 5-59\% in men, with the highest rate reported in either sex from sexually transmitted infection (STI) clinic and in other high risk population (Karyakarte and Damle 2003). The undesirable side effects associated with this classical drug, as well as the development of resistance, are encouraging research into alternative synthetic or natural compounds effective for the treatment of hydatid disease . In this regard, most studies have been focused on activity of natural products from algae chlorophyta and cyanophyta 
, mainly due to their accessibility and use in traditional medicine. A range of pharmacological activities have also been observed with extracts of chlorophyta and cyanophyta as antibacterial , antifungal ,anticancer , and anti-parasitic compounds (Takeaki etal., 2003 and Abass, 2010).

\section{Material And Methods :}

\section{1- Microalgae and methanol extract preparation :}

Hapalosiphon welweschii were cultured by using Chu - 10 medium, briefly, jars of 5 liters were filled with 3 liters of liquid medium, inoculated with desired algae, and then transferred to growth chamber at $12-25{ }^{\circ} \mathrm{C}$. Constant illumination was used at $60 \mu \mathrm{E} \backslash \mathrm{mlcm}$ intensity with white fluorescent loup. Algae was harvested at the medium of stationary phase by using GFA pre weighed filter paper and centrifuge methods . Freeze - dried weighted again to reach a fixed weight of dried microalgae. The methanol extracts to be prepared; dry mass in ratio (1: $15 \mathrm{~g} / \mathrm{ml}$ ) was extracted using magnetic starrier through 24 hours. The precipitates were removed by filtration and left to dry until use, and then the filtrates were concentrated at room temperature .

\section{- GC-Mass spectra analysis:}

Gas chromatography - mass spectra of fraction applied for the identification and determination of the molecular weight and chemical formula and structure of the purified chemical active compounds . it was done in Bruker company, Iran and Al- Elbait university in Jordin.
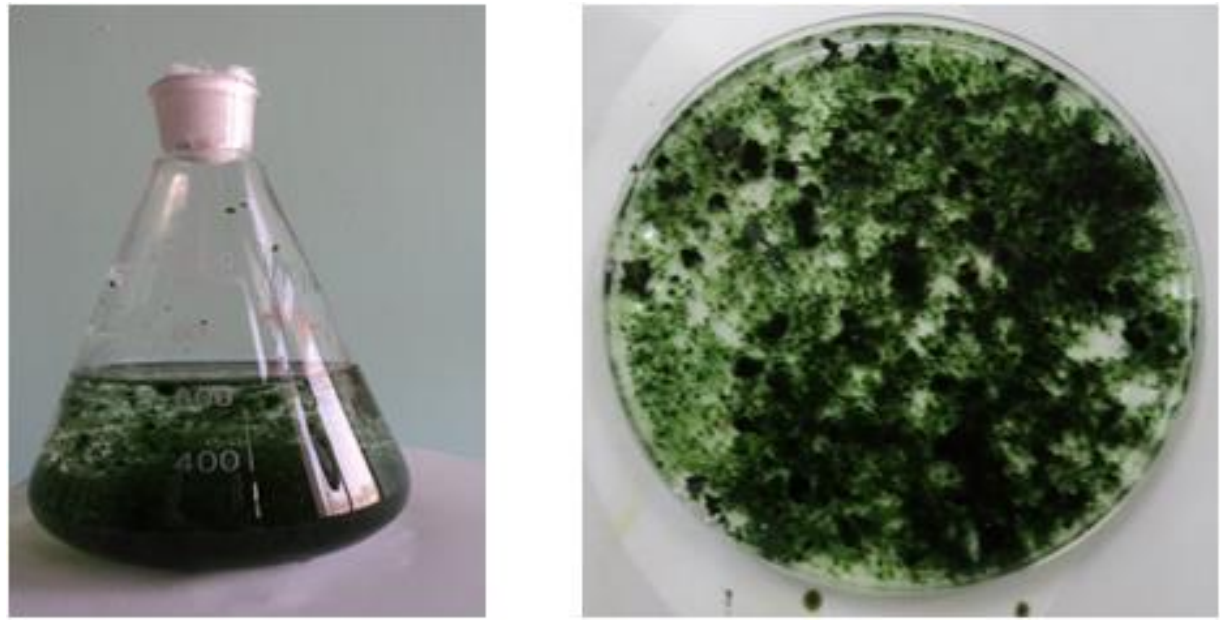

Figure (1) : Microalgae Hapalosiphon welwischii in culture

\section{2- Collection of Parasite sample and culturing :}

High vaginal swab (HVS ) was collected from women infected with $T$. vaginalis after the insertion of speculum. the swab was inoculated into Kupferberg trichomonas broth media (Ph:6) and incubated at $37 \mathrm{C}^{\circ}$ (Swygard et al.,2004) and left for seven days , there after, three tube of parasite culture were treated with the extract in three concentration only $(100,150,200 \mu \mathrm{g} \backslash \mathrm{ml})$, lethal concentrations were chose from $\mathrm{LD}_{50}$, forth tube consider as control sample without treatment . the four tube were microscopically examined and counting of parasite for seven days started with one hour. 


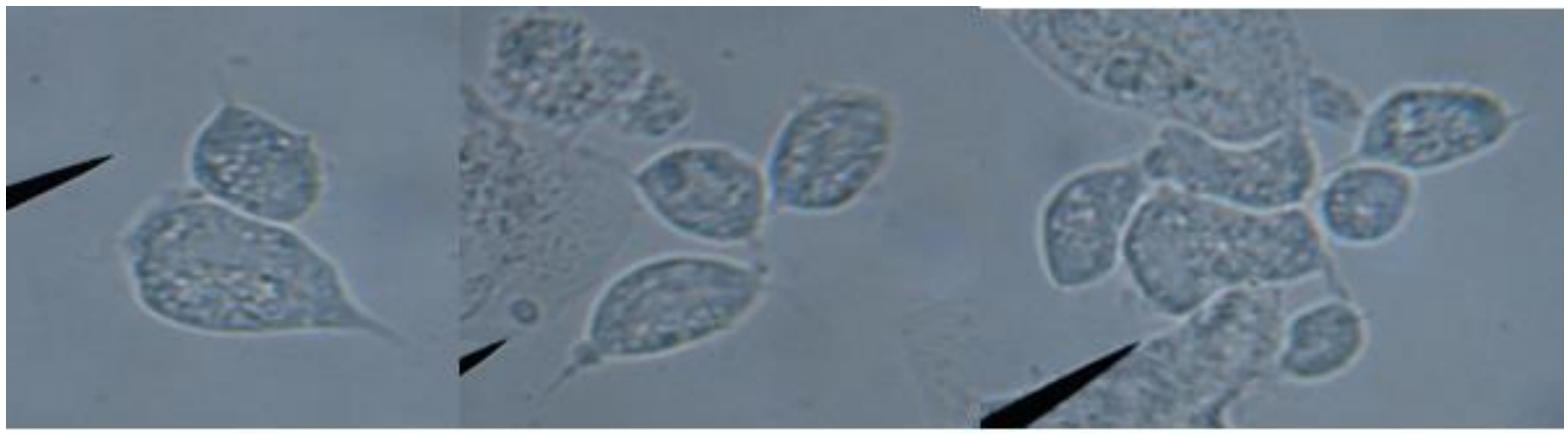

Figure (2) : Trichomonas vaginalis in vaginal discharge and culture

\section{$\underline{\text { Results }}$}

Methanol extract of Hapalosiphon welweschii recorded high activity at $200 \mu \mathrm{g} \backslash \mathrm{ml}$ after 2 - days post treatment, while $100 \mu \mathrm{g} \backslash \mathrm{ml}$ has explained activity after 4 days and $150 \mu \mathrm{g} / \mathrm{ml}$ revealed activity after 3 days - post treatment. The previous results of extract activity reported after days for each concentration till use, but the activity of this product were observed after one hour as explain at the following table(1) :

Table (1):Viability of Trichomonas vaginalis treated with methanol extract of Hapalosiiphon welweschii

\begin{tabular}{|c|c|c|c|c|c|c|c|c|c|}
\hline \multirow[t]{2}{*}{$\begin{array}{l}\text { Concentration } \\
\mu \mathrm{g} \backslash \mathrm{ml}\end{array}$} & \multicolumn{9}{|c|}{ time of treatment $\backslash$ days } \\
\hline & $1 \mathrm{~h}$ & $4 \mathrm{~h}$ & 1 day & 2 days & 3 days & 4 days & 5 days & 6 days & 7 days \\
\hline 100 & 70.0 & 61.4 & 42 & 31.66 & 20 & $\mathbf{0}$ & 0 & 0 & 0 \\
\hline 150 & 66.21 & 50 & 38.66 & 26.33 & $\mathbf{0}$ & $\mathbf{0}$ & 0 & $\mathbf{0}$ & 0 \\
\hline 200 & 57.33 & 42.6 & 23.66 & 0 & $\mathbf{0}$ & 0 & 0 & 0 & 0 \\
\hline Control & 92.9 & 88.0 & 80.75 & 78.22 & 75.0 & 67.1 & 59.8 & 54.2 & 50.5 \\
\hline L.S.D. & \multicolumn{9}{|l|}{0.854} \\
\hline \multicolumn{10}{|c|}{ Significant differences, $\mathrm{P} \leq \mathbf{0 . 0 5}$} \\
\hline
\end{tabular}

\section{GC- Mass spectrum of methanol Extract of microalgae :}

The GC - Mass spectrum (Fig,1) of the methanol extract of $H$. welweschii revealed that are 22 peaks of different sizes. The results of spectrum showed that Triazolo[1,5-a] pyrimidine carboxylic acid consist $13.28 \%$ of the total methanol extract followed by Diterpine ( $13.03 \%$ ) as illustrated below :

Table ( 2) :bioactive chemical compounds of methanol extract of $H$. welweschii

\begin{tabular}{l|c|c|l|c|}
\hline Peak & R.T. & \% of total & \multicolumn{1}{|c|}{ Compounds } & M.W. \\
& & & & \\
\hline $\mathbf{l}$ & 24.628 & 13.28 & - Triazolo[1,5-a] pyrimidine carboxylic acid & 164.12 \\
\hline $\mathbf{2}$ & 27.673 & 13.03 & - Diterpine & 286.45 \\
\hline $\mathbf{3}$ & 28.951 & 4.36 & $-3,7,11,15$, tetramethyl- 2- hexadecan-1-ol & 296 \\
\hline $\mathbf{4}$ & 30.362 & 2.42 & -18 - Nonadecen-1-amine & 283 \\
\hline
\end{tabular}




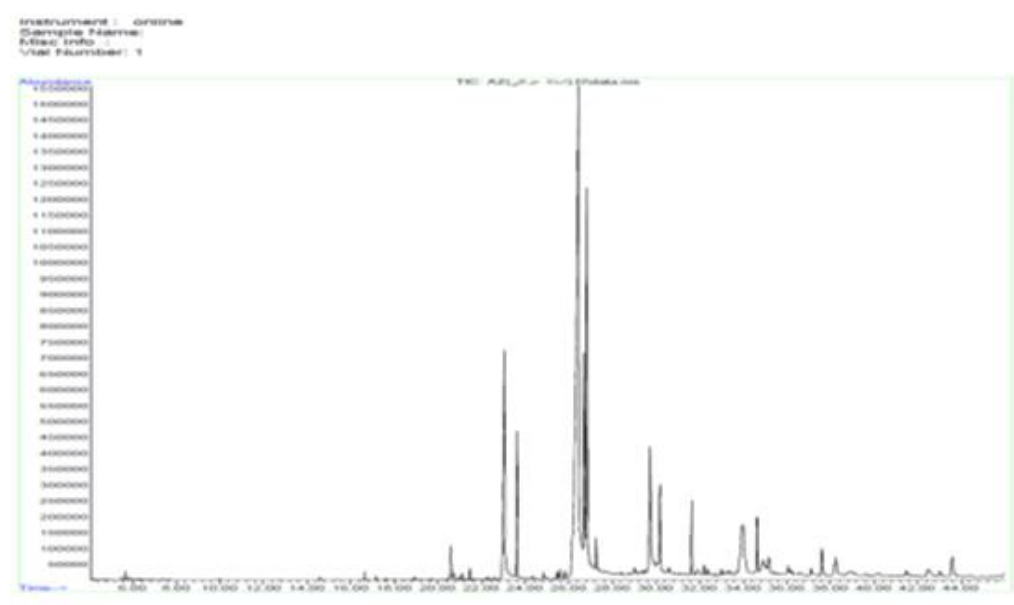

Figure (3) : GC- Mass spectrum of Methanol extract

\section{Discussion :}

Natural products have been the source of therapies since the advent of traditional medicine and healing; it remains a dominant source to date. The World Health Organization (WHO) estimates that $80 \%$ of the world's inhabitants depend mainly on traditional medicine for their primary health care (Tuney etal., 2006 ; Taran etal., 2009 ). Three concentrations of the methanol extract of $H$. welweschii were used in the present study and it had an in vitro activity against $T$. vaginalis and the time plays an important role in the treatment since the decreased concentration leads to increase the time of treatment . The activity of the methanol extract could be explained by the presence of the compound Triazolo[1,5-a] pyrimidine carboxylic acid.It is difficult to speculate the mechanism by which these bioactive compounds act as parasitecidal agents. In this regard Sepulveda-Boza and Cassels (1996) suggested that many bioactive chemical compounds exhibited their parasitecidal activity by virtue of their interference with the redox balance of the parasites, acting either on the respiratory chain or the cellular defenses against oxidative stress. It is also known that some bioactive compounds act by binding with the DNA of the parasite. For example, dihydroorotate dehydrogenase (DHOD), the fourth enzyme in the de novo pyrimidine biosynthetic pathway, is essential to parasites, including the electron acceptor capacity and cellular localization (Morales-Landa etal., 2007). In this way, it has been recently demonstrated that the methanol extracts of brown algae Ishige okamurae, Fucus evanescens, and Pelvetia babingtonii contain potent noncompetitive inhibitors against Trypanosoma cruzi DHOD (Takeaki etal., 2003 and Morales-Landa etal., 2007).

\section{References :}

- Abbas, F.N. (2010). The study of the biological activity of some plant extracts against some causes superficial candidiasis. M.Sc. Thesis, College of Science, University of Basrah.

- Karyakarte , R . and Damle , A . (2004) . Medical Parasitology . Arunabha Sen ,Books and Allied (P)LTD,8/1 Chintamoni Das Lane ,Kolkata .

- Morales-Landa, J .L.; Zapata-Pérez, O.; Cedillo-Rivera, R.; Segura- Puertas, L. and Alvarez R.J. (2007). Antimicrobial, antiprotozoal and toxic activities of Cnidarian extracts from the Mexican Caribbean Sea. Pharm. Biol. 45:37-43

- Sepulveda-Boza, S. and Cassels, BK. (1996): Plant metabolites active against Trypanosoma cruzi. Planta Med 62: 98-105.

- Swygard, H. ; Sena, A.C. ; Hobbs , M.M. and Cohen , M.S. ( 2004) . Trichomoniasis : clinical manifestation , diagnosis and management. Sex. Transm. Infect. , 80:91-95.

- $\quad$ Schwebke, J.R. and Burgess , D. (2004). Trichomoniasis . Clin. Microbiol. Rev. , 17: 794 - 803.

- Taran,M.; Azizi,E.; Shikhvaisi, A. and Asadi , N.(2009). The Anthelmintic Effect of Pistacia khinjuk Against Protoscoleces of Echinococcus granulosus. World J. Zoo., 4: 291-295. 
- $\quad$ Takeaki, O. ; Ryuta, T. ; Takeshi, N. ; Takashi, A. and Yuto, K. (2003). Screening for anti- Trypanosoma cruzi dihydroorotate dehygrogenase from marine algae collected from Japanese coasts. Coast Bioenviron 2: 67-76. 